\title{
The Impacts of Climate Change Risks on Financial Performance: Evidence from Listed Manufacturing Firms in Vietnam
}

\author{
Nguyen Thuc Huong GIANG ${ }^{1}$, Thai Minh HANH ${ }^{1}$, Pham Thu HIEN ${ }^{*}$, Nguyen Trong TRINH ${ }^{1}$, \\ Nguyen Thi Khanh HUYEN ${ }^{1}$, Vu Huyen TRANG ${ }^{1}$ \\ ${ }^{1}$ Department of Financial Management, School of Economics and Management, \\ Hanoi University of Science and Technology, Hanoi, Vietnam \\ ${ }^{*}$ Corresponding author: hien.pt182301@sis.hust.edu.vn
}

\begin{abstract}
Adverse climatic conditions increase greater systematic risk for companies throughout the global economy. Only a few studies directly examine the consequences of climate-related risk on financial performance of publiclylisted firms across the globe especially in Vietnam. The manufacturing industry is one of the sectors most significantly affected by climate change because it is characterized by high exposure, sensitivity and substitution.

\section{Research purpose:}

This study focuses on examining the impact of climate change risks on the financial performance of manufacturing enterprises in Viet Nam.

\section{Research motivation:}

Adverse climatic conditions increase greater systematic risk for companies throughout the global economy. Only a few studies directly examine the consequences of climate-related risk on financial performance of publiclylisted firms across the globe especially in Vietnam. The manufacturing industry is one of the sectors most considerably affected by climate change because it is characterized by high exposure, sensitivity and substitution.
\end{abstract}

Research design, approach and method:

This study uses both quantitative and qualitative methods, applying an econometric regression model to examine the relationship between climate change risk and firm performance through control variables. After that, we develope a hypothesis and methodology to analyze how climate change can affect financial performance. The data is obtained from the financial statements of 144 listed companies between 2015 and 2019.

\section{Main findings:}

Empirical analysis shows that there is a correlation between climate change and the financial performance of manufacturing companies. The results indicate that climate change has a negative impact on financial performance. Humidity risk has a significant and negative correlation with the financial performance of companies. However, some independent variables such as temperature, sunshine hours, or rainfall show negligible impacts on financial performance.

\section{Practical/ managerial implications:}

This research will help businesses and practitioners be aware of the direct impact of climate change on firm performance. Therefore, in order to cope with the climate change risks, manufacturing enterprises need to develop action plans in response.

Keywords: climate change, natural disasters, climate change risk, financial performance, manufacturing firms, Vietnam.

\section{INTRODUCTION}

The rapid development of industrialization and urbanization have increased the concentration of greenhouse gases in the atmosphere, which have led to an increase in the frequency and severity of climate events worldwide and generate a huge impact on the ecological environment and socioeconomic system. There is a growing perception that natural disasters and extreme weather events associated with climate risks can potentially and unintentionally affect the financial performance of businesses. According to the Global Risk Report (2020) the top five risks are extreme weather events, failed climate action, natural disasters, biodiversity loss and man-made environmental disasters out. According to the Global Climate Risk Index (CRI) Report (2020) published by Germanwatch, in the period 1999-2018, Vietnam ranked 6th among the countries most negatively impacted by climate change. The impact of climate 
change, with extreme phenomena such as temperature rise, drought, sea level rise... shrinking agricultural land area, reducing crop and livestock productivity, reducing the supply of raw materials for industry processing, increasing energy consumption, production costs in many industries. The World Bank forecasts that climate change could affect $1.5 \%$ of Vietnam's gross domestic product (GDP) from now to 2050. By the United Nations Economic Commission for Latin America and the Caribbean (Bradshaw, 2003), the economic impact of disasters can be classified in two ways: direct impact (damage- destruction of all or part of property) and indirect effects (loss-change in economic flows). Many businesses have realized the consequences of climate change risks and they are in the process of reducing anthropogenic greenhouse gas (GHG) emissions, mainly due to population growth and economic activities (Emodi et al., 2019). In addition, the Intergovernmental Panel on Climate Change (IPCC), the International Energy Association (IEA), the National Environment Protection Organization (UNEP) have tried to address the issue potential global warming (GWP) by reducing anthropogenic carbon emissions where temperature rise should be limited to less than $21^{\circ} \mathrm{C}$ above pre-industrial levels, and pursue target $1,51^{\circ} \mathrm{C}$ with the goal of mitigating the impact of climate change (Mollah, 2020). Climate change mitigation strategies help the cement industry to effectively reduce GHGE. Electrical energy emission reduction, process emission reduction, emission avoidance and reduction, fuel emission reduction and mitigation management measures have been identified (Sachin, 2019).

The factors affecting the financial performance of the manufacturing industry mainly focus on organizational factors, climate change factors and social factors in the existing studies (Sun et al., 2020). The health of the economy depends heavily on the development of the manufacturing sector. 2020 is a challenging year for the Vietnamese economy, with a growth rate of $2.9 \%$, the lowest increase in the period 2011-2020, but in the context of the complicated Covid-19 the processing and manufacturing industry still plays a key role, leading the growth of the economy with an increase of $5.8 \%$. Despite playing an important role in socio-economic development, the manufacturing industry is increasingly being affected by climate change because it is characterized by high exposure, sensitivity and substitution. Therefore, our research focus on the manufacturing industry.

In Vietnam, our study is considered to be an exploratory study focusing on the impacts of climate change on financial performance in Vietnam. At the 24th Conference of the Parties to the United Nations Framework Convention on Climate Change (COP 24) taking place in Poland, Germanwatch Foundation has released a report on a long-term climate risk index 2019. This report has listed the 10 countries most affected by climate change, Vietnam ranks 6th in this list.

The structure of the paper is as follows: Section 1 introduces the general contents of the issue. Section 2 provides an overview of the literature. Section 3 presents the hypotheses and then authors provide the research methodology in Section 4. Section 5 describes the data. Section 6 reports experimental results and discussion. We have concluded the paper with policy implications in the last section.

\section{LITERATURE REVIEW}

Climate change is an abnormal change in weather. This could be a change precipitation that a place would normally receive in a year, or it could be a change in a place's usual temperature over a month or season (NASA Educational Technology Services, 2018). Climate change has significant impacts on nature and human activities, it affects both directly and indirectly on economic, cultural, and social activities. Climate risk is the likelihood that a hazardous climate event and its consequences will affect a particular system that system's vulnerability (ISET, 2013). As global temperatures are expected to continue to rise, it is increasingly important to understand and predict the impact of climate change risks on economic activity (Dell et al., 2014). Activities such as agriculture, forestry, fishing, and mining are directly affected by extreme climate events because these industries are vulnerable to climate change. Industries which are less dependent on the natural environment are also affected by climate change because the market can link all sectors (Sun et al., 2020). As a result, climate change risks have a wide-ranging impact on manufacturing activity in all types of industries, either directly or indirectly. Currently, global temperatures are expected to continue to rise, which increase the difficult in predicting the impact of climate change risks on economic activities (Dell et al., 2014). However, according to (IPCC, 2014), climate change risks may bring both opportunities and threats to economic and social activities.

The impacts of climate change on many industries have received widespread attention. Climate change risks also affect the development of industry and services (Zhang and Miu, 2001). The intensity and frequency of extreme climate events can cause damage to the construction of the mining industry (Pearce, 2019). Since industrial sectors can be highly interdependent, they can suffer economically even if they themselves are not directly affected by the disaster (Milad and Christopher, 2015). The sugar industry in Australia has traditionally been of high economic value but is also geographically dispersed, vulnerable to the effects of climate change (Rosenzweig, 2014). In the industrial sectors, the effects of climate change will affect the processing industry, especially the processing of agricultural products (Chinh, 2020). Climate change will have a significant impact on the coastal industrial zone. Raw materials for 
industry, particularly for food processing, textile, and garment sectors, will be substantially decreased since they will not be provided from raw material locations in Vietnam's Mekong Delta provinces, which are the most extensively inundated. Increasing temperature increases energy consumption in industries, increases the cost of ventilation and cools of mining pits and reduces the efficiency and output of power plants (Dat and Thu, 2013). In one study in wine industry, local climatic conditions, in particular high level of temperature and water, were the factors that most influenced both wine production and adaptive behavior in the wine industry (Eva et al., 2018). Global warming will affect wine and wine production, not only in the physiology and biochemistry of the vine, but also in the production methods used to make wine (Schultz, 2010). Another study was assessing the vulnerability of the Australian uranium industry to climate-related impacts, based on surveys carried out around currently active uranium mines has been shown that because of future climate change, the local uranium industry could be affected by more intense and frequent extreme weather events, leading to the potential for operational disruptions and damage to facilities or mining infrastructure (Pizarro et al., 2017). Clearly, climate change concerns have far-reaching global implications for the business.

Firms in the manufacturing sector suffer the most losses and damage from floods, as they are related to resilient infrastructure (i.e. heavy inputs and machinery for the production process output) and is characterized by a strong reliance on the system's upstream supplier. For SMEs, flooded production sites pose a serious risk to their viability, as flooding severely affects their ability to continue operating business over time (Roxana et al., 2020). Climate change is a factor for companies to strengthen cost management, raise awareness about environmental protection, and check to improve financial inclusion. In the long run, companies which actively implement environmental governance and safeguards can achieve a win - win situation between the environment and finance (Yang and Wang, 2016).

Climate risks are increasingly recognized as a serious and worldwide concern for both governments and businesses. However, much uncertainty still exists about the relation between climate risks and financial performance. Few studies have directly examined the consequences of climate-related risk on financial performance by publicly listed firms across the globe. Although some research has been carried out on the effect of global climate risk on firm performance using cross-country data (Huang et al., 2018), there is extraordinary little scientific understanding of the impact of climate risk as a determinant of financial performance on manufacturing firms. This study aims to address this research gap.

Most previous studies have focused on the impact of climate change on financial performance at the general level or in one sector other than the manufacturing sector. For example, Sun et al. (2020) examined the impact of climate change risks on the financial performance of the mining industry in China, providing a more complete picture of the adverse effects of the climate risks to the financial performance of businesses. Or another study by Asuka et al. (2012) investigated on the agglomeration industry in Tokyo, Japan....

In Vietnam, there are some studies on the factors influencing on the financial performance of enterprises, (Dung et al., 2020..) but climate change is not among the studied factors. Besides, research on the effects of climate change only focuses on macro indicators such as GDP, market prices or behavior indicators (business behavior). Studies focus on the impact of climate change on the development and economic performance are extremely limited and there is no previous study on the impact of climate change on financial performance in the Vietnamese manufacturing industry. Therefore, our findings could be of interest to regulators, policy planners, investors and also manufacturing companies' leaders in Vietnam.

\section{HYPOTHESIS}

\subsection{Mechanism}

Climate change risks can impact to a company's financial performance through both direct and indirect channels. The direct impact of climate change risks on financial performance could create a change in a company's production and operations, which can lead to the changes of assets, raw materials, production techniques, supporting systems, etc. The indirect impact is to change the operating and competitive environment including environmental regulation, climate policy, stakeholders's attitudes, litigation cases and so on. Both directly and indirectly impacts will also alter the financial viability and performance of the company (Sun et al., 2020).

According to Intergovernmental Panel on Climate Change (IPCC, 2007), global climate change has and will affect all aspects of nature and society, in which infrastructure is an important object. This makes the company unable to operate normally and incurs additional costs. According to a report by the Institute of Hydrometeorology and Environmental Science (2011), during the production process, the increased temperature easily damages equipment, hinders or disrupts normal development activities. Rising sea levels due to global warming have forced many companies to relocate production and pay the corresponding relocation costs. Companies whose locations are closely related to the distribution of capital goods face the risk of high costs. Therefore, for companies whose core operations depend on natural conditions, climate change will result in loss of physical assets, increased costs, business disruptions and impacts operating income, will have a negative impact on the financial 
performance of the company. Natural disasters amplified by climate change can disrupt companies' production processes and cause significant damage to their profits (Hong et al., 2019). For companies that manufacture goods, the value chain includes the steps involved in getting a product from conception to distribution, such as raw material procurement, production functions, and product marketing. Climate change will affect raw materials supply for production. These changes directly affect suppliers, workers, and market demand in the company's production value chain. Thus, in the long term, climate change will limit the production capacity of enterprises, change capital structure, change costs, and reduce profits of the business itself. Companies also need to adapt their business models to cope with the risks posed by climate change.

Climate change has an indirect impact on a company's financial performance through market opportunities and corporate reputation. The results of a survey conducted by Accenture PLC a Fortune Global 500 company in April 2020 show that, $60 \%$ of consumers want to buy environmentally friendly products. According to the Worldbank, sustainability is a factor that modern consumers care in their shopping behavior, with $71 \%$ of consumers worldwide are willing to contribute to a sustainable living environment through spending on products green (Industry and Commercial Information Center). They are more sympathetic to responsible brands, which can help make the world cleaner. Therefore, businesses will also have to change their production and business models, from standard and sustainable sourcing to build a production process that does not pollute, negatively impact the environment, distribute green, environmentally friendly products to consumers. Through the implementation of sponsorship for environmental protection, companies can enhance brand value, gain reputation and growth in the future. In the short term, companies will have to invest, upgrade more equipment, production materials, technology-science and establish appropriate production models. However, in the long run, they can improve the resource efficiency, reduce environmental compliance costs, and increase company performance. If companies can proactively respond to climate change and take initiatives to disclose emissions information, it is likely that they got a signal indicate that they will do well in the future.

\subsection{Average temperature:}

Climate change changes workforce productivity as high temperatures limit employees' time outdoors. Sudarshan et al. (2014) provided empirical evidence indicating that changes in surface temperatures may directly impact manufacturing output through their impact on worker productivity in Indian manufacturing. These examples and anecdotes provides a signal that at least in one city, where temperatures have been rising with the formation of local heat islands, firm owners believe that temperature has an impact on worker performance and through that mechanism on output and profitability.

High temperatures have been linked with lower aggregate economic output in many parts of the world. Both labor and capital intensive firms show sensitivity to high temperatures. By mid-21st century, if no additional adaptation occurs, climate change will reduce Chinese manufacturing output annually by $12 \%$, equivalent to a loss of $\$ 39.5$ billion in 2007 dollars (Zhang et al., 2017). High temperatures not only cause physical discomfort and fatigue but can also affect cognitive functioning (Hancock et al., 2007). The higher temperatures lower the ability of lubricants to reduce surface friction between mechanical components (Mortier et al., 1992); and lower the processing speed of computers (Lilja, 2000).

Therefore, we hypothesize:

H1-a: Average temperature has a negative impact on financial performance

\subsection{Sunshine hours:}

Health and performance impairments provoked by thermal stress are societal challenges geographically spreading and intensifying with global warming. People face the risk of heat stress when working under high temperature, or heat stroke, cramps, fainting, heat exhaustion. However, we spend more money on a product when it's sunny outside and when there's more daylight. It's hardly surprising we all pay more for ice cream during the summer and the sales of ice-cold beers skyrocket when there's more sunlight (Fromberg, 2016). Kliger et. al. (2015) shows us that the daylight duration has a significant positive effect on selling prices of art, a non-durable good. Besides, the potential of solar energy is also highly appreciated when Vietnam is a country with a lot of sunshine in the year with high radiation intensity in the central and southern regions, creating potential for development. Renewable energy is very large, helping the power generation industry to be increasingly promoted.

It can be seen that sunshine hours has a two-way effect for each industry group. In our research paper, we hypothesize:

\section{H1-b: Sunshine hours have a negative impact} on financial performance

\subsection{Rainfall index:}

The impact of rain-waterlogging risk on the financial performance of listed mining companies is not significant since there are only a few mining companies that are sensitive to rainwaterlogging (Sun et al., 2020). Meanwhile, Bhat et al. (2015) concluded that the rainfall too have significant impact on salt production, the results of 
model show if there is $1 \mathrm{~mm}$ increase in rainfall will lead 0.078 ton decrease in salt production.

Changes in rainfall change the humidity on the ground, change the radiation status, affect plant species. Changes in rainfall can also cause widespread drought. Among the natural disasters that can be aggravated by climate change, drought is the one that has the greatest impact on economic activities (Huynh et al., 2020; Hong et al., 2019; Lesk et al., 2020; Hong et al., 2019; Lesk et al., 2016). Throughout Latin America and the Caribbean, the effects of drought are significant, including falling river levels, thereby impeding inland transportation routes, and reducing crop and food production, leading to poorer conditions. Food insecurity in many regions is worsening (Climate Status Report in Latin America and the Caribbean 2020).

Rainfall changes also cause floods and landslides, leading to damaged infrastructure and damage. Thus, we hypothesize:

H1-c: Rainfall index have a negative impact on financial performance

\subsection{Humidity index:}

Humidity is an important factor in people's perception of comfort. Excessive levels on the shop floor can result in a significant drop in productivity. It can also lead to a build-up of condensation, mist or mould, which will damage product quality, the factory's equipment and the building itself. The control of humidity levels is particularly critical in the food industry. Moisture is a bacteria carrier: it brings the risk of contamination and can lower the durability and shelf life of a product (Langford, 2019).

In production, especially in food production, when the air humidity is too high, it will reduce the quality of the output products, even causing spoilage, rancidity, mold, which greatly affects the economy. In fact, the effect of reduced humidity in the vital space makes us physically weak, reduce labor productivity, work and be susceptible to diseases due to a weakened immune system.

In our research paper, we hypothesize:

H1-d: Humidity index have a negative impact on financial performance

\subsection{Model settings}

\section{METHODOLOGY}

This study aims to determine the impact of climate change risks on the financial performance. The study scope was Vietnam's manufacturing industry in the period 2015-2019. We formally investigate the impact of climate risk on a company's financial performance by estimating the following regression model:

$$
\begin{aligned}
& \text { Roa }_{i t}=\beta_{0}+\beta_{1} \text { Sun }_{t}+\beta_{2} \text { Rain }_{t}+\beta_{3} \text { Humid }_{t} \\
& +\beta_{4} \text { Temp }_{t}+\beta_{5} \text { Debtas }_{i t} \\
& +\beta_{6} \text { Growth }_{i t}+\beta_{7} \text { Size }_{i t} \\
& +\beta_{8} \text { Holder }_{t}+\beta_{9} \text { Firmtype }_{t} \\
& +\beta_{10} P G R D P_{t}+\beta_{11} \text { Human }_{t} \\
& +e_{i t}(1) \\
& \text { Roe }_{i t}=\beta_{0}+\beta_{1} \text { Sun }_{t}+\beta_{2} \text { Rain }_{t}+\beta_{3} \text { Humid }_{t} \\
& +\beta_{4} \text { Temp }_{t}+\beta_{5} \text { Debtas }_{i t} \\
& +\beta_{6} \text { Growth }_{i t}+\beta_{7} \text { Size }_{i t} \\
& +\beta_{8} \text { Holder }_{t}+\beta_{9} \text { Firmtype }_{t} \\
& +\beta_{10} \text { PGRDP }_{t}+\beta_{11} \text { Human }_{t} \\
& +e_{i t}(2) \\
& \text { Rosit }_{i}=\beta_{0}+\beta_{1} \text { Sun }_{t}+\beta_{2} \text { Rain }_{t}+\beta_{3} \text { Humid }_{t} \\
& +\beta_{4} \text { Temp }_{t}+\beta_{5} \text { Debtas }_{i t} \\
& +\beta_{6} \text { Growth }_{i t}+\beta_{7} \text { Size }_{i t} \\
& +\beta_{8} \text { Holder }_{t}+\beta_{9} \text { Firmtype }_{t} \\
& +\beta_{10} P G R D P_{t}+\beta_{11} \text { Humant }_{t} \\
& +e_{i t}(3)
\end{aligned}
$$

\subsection{Dependent variables}

The dependent variable of this paper is the company's financial performance measured by Return on Assets (ROA), Return on Equity (ROE) and Return on Sales (ROS). Financial performance in this study is defined as the firm's ability to manage and control its resources (Hamid and Elvin, 2016); (Utama and Mirhard, 2016); (Harymawan et al., 2019). Widiyanti et al. (2019) states that firm performance is a measurement that shows the success of the managements in achieving their goals.

Normally, researchers only focus on one variable that represents for the financial performance. For example, Return on Assets (ROA) plays an important role in assessing a company's financial performance (Peters and Mullen, 2009). The higher the return on total assets of the company, the higher the efficiency of using assets of the company, the higher the profit, the stronger the profitability, the better the financial performance of the company, and vice versa. (Sun et al., 2020). However, through looking at previous studies on the choice of the dependent variable that represents the company's financial performance, we considered that we have to add on two dependent variables such as ROE and ROS to present the most nuanced perspective on the results.

Research by Mahfuzah and Raj (2012); Edith and Quentin (2021) also gives the results that return on total assets (ROA) or return on equity (ROE) play an important role in assessing a company's financial performance with other variables. Besides, the study of Atta et al. (2012) also takes the variable that represents return on equity (ROE) as a measure for financial performance. In addition, the business operations of the enterprise also play a very important role in showing the financial performance of the company. Research by Tan et al. (2015) has chosen the variable return on sales (ROS) to show the financial performance. 


\subsection{Independent variables}

Climate change affects to the exploration, extraction, production and transportation in the manufacturing industry (Pearce et al., 2011), increasing connectivity to the rear (forests, floods, storms) and affects to the most viability of production activities and potentially increasing campaign costs, changing and stopping most bases built on the theory of the normal environment of life, and therefore it is not adapted to climate change (Ford et al., 2011; Pearce et al., 2011).

We select four independent varibles of climate change in the model such as average temperature, rainfall, sunshine hours, and humidity because these are the four most favorable indicators in assessing climate risk through the data set provided by the General Statistics Office in Vietnam (GSO).

The variable of temperature (Temp) and sunshine hours (Sun) play an important role in dedicating the climate change risks. Climate change is most visible through global warming. According to a report by the Hydrometeorological Center of Vietnam in 2018, the average temperature increases by 1-2 degrees per year, the number of sunny hours is increase and the rain index is decrease. According to the report of the Ministry of Natural Resources and Environment in 2018, these indicators strongly affect the industry in general and the manufacturing industry in particular. Some previous research papers show that high temperature affectst the working environment and reduce labor productivity (Su et al., 2018; Sun et al.,2020). The higher temperature and the increase of sunshine hours index will affect the quality of labor due to severe weather, reduce labor productivity, and negatively affect the firm performance.

Second factor is rainfall index (Rain), which according to the research of Roxana et al. (2021), regarding the negative impact of the situation of high rainfall causing flooding, production activities of enterprises have been really affected. Previous study also pointed out the negative effects of rainfall, such as Wang et al. (2021).

The index of humidity (Humid) is an important variable when considering climate change in Vietnam and some regions with tropical monsoon climates. Previous research by Alan (2011); Haiyan et al. (2020) have shown the negative impact of humidity on human health in Asian countries. This also reduces labor productivity and indirectly affects the financial performance of enterprises.

\subsection{Control variables}

Although it is obvious that the impact of climate risks effect on both society and each businesses. However, there is no previous study in Vietnam that indicate the effects of climate change risk on firms. In line with prior literature (e.g., Dessi and Robertson, 2003; Sun et al., 2020,...), our regression model (equations 1) also includes several additional variables to control for a set of firm-specific observable characteristics that are likely to be correlated with firms' performance.

The first set of control variables includes: Capital structure (Debtas), Company size (Size), Shareholding ratio of controlling shareholders (Holder), Ownership structure (Firm_type) and Company growth (Growth).

Agency theory also suggests that the choice of capital structure can act as a disciplinary mechanism in mitigating these agency conflicts and thus contributes to an improvement on firm performance. More specially, the agency theory suggests that debt financing is one of the governance mechanisms to mitigate agency costs of equity capital and thus to enhance firm performance (Vijayakumaran et al., 2017).

More over, in many previous research, researchers demonstrate the relatsionship between capital structure and firm performance. According to Titman and Wessels (1988), capital structure negatively affects the financial performance of firms in China, while in Germany and Sweden it is positive. The recent contribution of Vijayakumaran (2018) expressed the concern about corporate structure decisions and financial performance of listed companies in China. He found a positive relationship between a company's financial performance and leverage ratio. Due to research findings, capital structure has a negative impact with statistical significance on financial performance (measured by ROA, ROE). The higher level of state ownership in ownership structure of a firm can lead to the better financial performance of the company (Quang and Xin, 2008).

Company size may have both positive and negative effect on financial performance. Evidence for a positive effect of size on financial performance is consistent with many previous studies . A positive relationship between company size and corporate performance is often considered as a stylized fact, as larger firms are expected to use better technology, be more diversified and better managed. Larger firms may also enjoy economies of scale in monitoring top management and have a higher capacity for taking risks (Himmelberg et al., 1999; Greenaway et al., 2014; Dixon et al., 2015). However, larger firms are likely to suffer from hierarchical managerial inefficiencies and thus incur larger agency costs (Williamson, 1967).

Wahidul and Khairul (2021) take a closer look at corporate governance, board practices and performance of shipping companies in Bangladesh. The regression analysis confirms that board ownership, management, board size, and firm size have no significant impact on firm performance.

Sun et al. (2020) shows that corporate growth has a positive effect on the financial performance of companies in the mining sector. The faster the company grows, the larger the market share, the greater the company's competitiveness and the higher the financial performance of the company. However, in contrast 
to the research of Zeitun and Tian (2007); Mahfuzah and Raj (2012); Imran (2016) again shows that company growth has a negative effect on business performance.

The second set of control variables includes two factors: Economic development (GRDP) and Human capital (Human).

In addition, firms with higher general and specific human capital are expected to show higher levels of performance than those with lower levels of general and specific human capital (Fatoki, 2011; Coleman, 2007).

These variables mentioned above play a crucial role in assessing the financial performance of companies. To examine the impact of climate change risks on the financial performance of Vietnamese listed companies, we select 144 companies in the manufacturing sector.

The impact of macroeconomic variables on the operating finances of companies in the mining sector is not significant (Sun et al., 2020). Nevertheless, another previous study suggested that GDP positively effects on firm performance Dung et al. (2020); Meyer et al. (2018) mentioned that when the GDP growth rate is high, the financials are booming, and the level of interest is better, the company's business will get better.

Table 1. Summary results from previous studies

\begin{tabular}{|c|c|c|c|c|}
\hline \multirow{2}{*}{$\begin{array}{l}\text { Primary } \\
\text { Variable }\end{array}$} & \multicolumn{4}{|r|}{ SIGN } \\
\hline & ROA & $\mathrm{ROE}$ & ROS & Citation \\
\hline Sun & - & - & - & Su et al. (2018), Sun et al. (2020) \\
\hline Rain & - & - & - & Leitold et al. (2021), Chunyuan et al. (2021) \\
\hline Humid & - & - & - & Barreca (2011), Yan et al. (2020) \\
\hline Temp & - & - & - & Sun et al. (2020) \\
\hline Debtas & $+/-$ & $+/-$ & 0 & $\begin{array}{c}\text { Sun et al. (2020), Titman and Wessels (1988) } \\
\text { Vijayakumaran et al. (2017) }\end{array}$ \\
\hline Growth & $+/-$ & $+/-$ & $+/-$ & $\begin{array}{l}\text { Sun et al. (2020), Zeitun and Tian (2007); } \\
\text { Mahfuzah and Raj (2012); Imran (2016) }\end{array}$ \\
\hline Size & $+/-$ & $+/-$ & $+/-$ & $\begin{array}{l}\text { Himmelberg et al. (1999); Greenaway et al. (2014); } \\
\text { Dixon et al. ( 2015); Williamson (1967) }\end{array}$ \\
\hline Holder & 0 & 0 & 0 & Wahidul and Khairul (2021) \\
\hline Firm_Type & + & + & + & Quang and Xin (2008) \\
\hline PGRDP & + & + & + & Dung et al. (2020) \\
\hline Human & + & + & + & Fatoki (2011); Coleman (2007) \\
\hline
\end{tabular}

(Source: Author's synthesis, 2021)

\section{DATA}

\section{Climate change risk data}

The index of climate change risks between 2015 and 2019 was published General Statistics Office of Vietnam. The climate risk index is based on the meteorological disaster loss data of Vietnam in the last five years, which is processed by average function climate change indicators. Following Huynh et al. (2020), we use the state location of a firm's headquarter to determine its exposure to climate risk. Prior research shows that firms' headquarter locations are usually close to their operations and core business activities (Coval and Moskowitz, 1999; Pirinsky and Wang, 2006; Ivkovi'c and Weisbenner, 2007; Hilary and Hui, 2009; Chaney et al. 2012; Korniotis and Kumar, 2013; Tuzel and Zhang, 2017). We use new data that measure are looking forward to physical climate risk at the firm level to examine the impact of climate risk on financial performance. The climate risk index includes four types: rainfalls index, temperature index, sunshine hours and humidity index. The average temperature is calculated by averaging the temperature over several years in the areas of listed companies. The sunshine hours are computed by averaging the hours over several years at the monitoring stations. The humidity index is determined by averaging the index at monitoring stations over five years. The rainfalls index is determined by averaging the index at monitoring stations over five years. The reason why we choose a stage from 2015 to 2019 because after the Paris Agreement many companies tend to be interested in how their activities affect climate change.

\section{Firm level data}

During the selection process from 225 manufacturing companies listed in the two major stock exchange markets - HOSE and HNX, we have selected 144 companies which guarantee satisfaction in terms of both micro and macro data to serve in the 
research process. 144 manufacturing firms were chosen and their financial statements from 2015 to 2019 were sorted and collected from Vietstock's database. We use the liability ratio to assess the company's capital structure, the total asset growth rate to assess the company's growth, and total assets to assess the company's size. In this paper, the assets of the firm at the end of the year are handled logarithmically to better reflect the company's magnitude. The share proportion of the largest holder is used to calculate the controlling shareholder's shareholding ratio. State-owned firms and private corporations are the two types of company ownership.

Table 2. Number of companies by Economic Production Sector

\begin{tabular}{c|c|c|c}
\hline \multirow{2}{*}{ STT } & Sector & $\begin{array}{c}\text { Number of } \\
\text { companies }\end{array}$ & Percentage (\%) \\
\hline 1 & Central Coastal Region & 14 & $9.72 \%$ \\
\hline 2 & Central Highlands & 4 & $2.78 \%$ \\
\hline 3 & Mekong River Delta & 4 & $2.78 \%$ \\
\hline 4 & Red River Delta & 39 & $27.08 \%$ \\
\hline 5 & Southeast & 78 & $54.17 \%$ \\
\hline 6 & Northern Midlands and Mountainous & 5 & $3.47 \%$ \\
\hline \multicolumn{2}{r|}{} & 144 & $100.00 \%$ \\
\hline
\end{tabular}

\section{(Source: Author, 2021)}

These 144 companies are divided into 6 economic regions of Vietnam. In which, the two economic regions that account for the largest proportion are Southeast and Red River Delta (> $20 \%)$. The remaining regions account for the following proportions: Central Coastal Region (9.72\%), Central Highlands (2.78\%), Mekong River Delta $(2.78 \%)$, Northern Midlands and Mountainous $(3.47 \%)$.

\subsection{City-level economic data}

This paper collects and sorts out the economic data of the prefecture level cities where the listed industry companies are registered from 2015 to 2019 by consulting General Statistics Office of Vietnam. Per capita GRDP (PGRDP) is used as an indicator to measure the level of economic development. Percentage of laborers aged 15 and over working in the economy who have received training by locality is used as an indicator to measure human capital. A description of all variables is shown in Table 1 as below.

\subsection{Financial Performance}

In the financial performance, we analyze 3 main indicators are the return on assets, return on equity and return on sales. The return on assets defined as the ratio of the net profit in the current year to the average total assets is used to measure the corporate financial performance (Marshall, 2021). Return on equity is a measure of financial performance calculated by dividing net income by shareholders' equity (Jason, 2021). Return on sales, is a ratio used to evaluate a company's operational efficiency which provides insight into how much profit is being produced per dollar of sales (Adam, 2021).

Table 3. Variable definition

\begin{tabular}{|c|c|c|c|c|}
\hline Variable Type & $\begin{array}{l}\text { Variable } \\
\text { Name }\end{array}$ & $\begin{array}{l}\text { Variable } \\
\text { Code }\end{array}$ & Variable Description & Unit \\
\hline \multirow{3}{*}{$\begin{array}{l}\text { Dependent } \\
\text { variable }\end{array}$} & \multirow{3}{*}{$\begin{array}{l}\text { Financial } \\
\text { performance }\end{array}$} & ROA & $\begin{array}{l}\text { Return on Assets: synthesize data from financial } \\
\text { statements }\end{array}$ & \\
\hline & & $\mathrm{ROE}$ & $\begin{array}{l}\text { Return on Equity: synthesize data from financial } \\
\text { statements }\end{array}$ & \\
\hline & & ROS & $\begin{array}{l}\text { Return on Sales: synthesize data from financial } \\
\text { statements }\end{array}$ & \\
\hline \multirow{3}{*}{$\begin{array}{l}\text { Independent } \\
\text { variable }\end{array}$} & $\begin{array}{l}\text { Average } \\
\text { temperature }\end{array}$ & Temp & $\begin{array}{l}\text { Annual average temperature from } 2015 \text { to } 2019 \\
\text { following general Statistics Office of Vietnam } \\
\text { data }\end{array}$ & Celsius \\
\hline & $\begin{array}{l}\text { Sunshine } \\
\text { hours }\end{array}$ & Sun & $\begin{array}{l}\text { Average total annual sunshine duration from } \\
2015 \text { to } 2019 \text { following general Statistics Office } \\
\text { of Vietnam data }\end{array}$ & Hours \\
\hline & $\begin{array}{l}\text { Rainfall } \\
\text { index }\end{array}$ & Rain & $\begin{array}{l}\text { Average total rainfall at some monitoring } \\
\text { stations from } 2015 \text { to } 2019 \text { following general } \\
\text { Statistics Office of Vietnam data }\end{array}$ & Millimetres \\
\hline
\end{tabular}




\begin{tabular}{|c|c|c|c|c|}
\hline & $\begin{array}{l}\text { Humidity } \\
\text { index }\end{array}$ & Humid & $\begin{array}{l}\text { Average total humidity at some monitoring } \\
\text { stations from } 2015 \text { to } 2019 \text { following general } \\
\text { statistics office of Vietnam data }\end{array}$ & Percentage \\
\hline \multirow{5}{*}{$\begin{array}{l}\text { Control } \\
\text { variables } 1\end{array}$} & $\begin{array}{l}\text { Capital } \\
\text { Structure }\end{array}$ & Debtas & $\begin{array}{l}\text { Asset-liability ratio was calculated the formula } \\
\text { as Total Liabilities / Total Assets }\end{array}$ & \\
\hline & $\begin{array}{l}\text { Company } \\
\text { growth }\end{array}$ & Growth & $\begin{array}{l}\text { Asset growth rate was identified by the formula } \\
\text { as Total assets at the end of the year - Total } \\
\text { assets at the beginning of the year / Total assets } \\
\text { at the end of the year }\end{array}$ & \\
\hline & $\begin{array}{l}\text { Company } \\
\text { Size }\end{array}$ & Size & $\begin{array}{l}\text { Natural logarithm of total assets at the end of the } \\
\text { year }\end{array}$ & \\
\hline & $\begin{array}{l}\text { Shareholding } \\
\text { ratio of } \\
\text { controlling } \\
\text { shareholders }\end{array}$ & Holder & $\begin{array}{l}\text { Number of shares held by the largest } \\
\text { shareholder/ total number of shares }\end{array}$ & \\
\hline & $\begin{array}{l}\text { Ownership } \\
\text { structure }\end{array}$ & Firm_type & $\begin{array}{l}\text { Virtual variables, } 1 \text { for state owned companies } \\
\text { and } 0 \text { for private companies }\end{array}$ & \\
\hline \multirow{2}{*}{$\begin{array}{l}\text { Control } \\
\text { variables } 2\end{array}$} & $\begin{array}{l}\text { Economic } \\
\text { development }\end{array}$ & PGRDP & Per capita GRDP & $\begin{array}{l}\text { Million's } \\
\text { dong }\end{array}$ \\
\hline & $\begin{array}{l}\text { Human } \\
\text { capital }\end{array}$ & Human & $\begin{array}{l}\text { Percentage of laborers aged } 15 \text { and overworking } \\
\text { in the economy was collected from general } \\
\text { statistics office of Vietnam data }\end{array}$ & \\
\hline
\end{tabular}

(Source: Author, 2021)

\section{RESULT AND DISCUSSION}

\subsection{Descriptive summary}

The statistics show the profitability of the companies in the study period with average ROA, ROE, ROS being $7 \%, 14 \%$, and $6 \%$ respectively. The highest values of ROA, ROE, and ROS are $72 \%$,
$293 \%$, and $168 \%$, respectively. Three financial performance indicators have above-average standard deviations $(8 \%, 15 \%, 19 \%)$, indicating that the financial performance of companies in the manufacturing industry is significantly different.

Table 4. Summary statistics

\begin{tabular}{lrrrrr}
\hline & N & \multicolumn{1}{c}{ Minimum } & \multicolumn{1}{c}{ Maximum } & Mean & Std. Deviation \\
\hline ROA & 720 & -.36 & .72 & .0741 & .07637 \\
ROE & 720 & -1.69 & 2.93 & .1359 & .19222 \\
ROS & 720 & -2.01 & 1.68 & .0597 & .15048 \\
Debtas & 720 & 0.00 & 1.29 & .4559 & .20636 \\
Totalin & 720 & -.86 & 4.34 & .1142 & .32675 \\
Lnsize & 720 & 13.22 & 32.25 & 27.3092 & 1.97513 \\
Holder & 720 & 0.00 & .98 & .3953 & .22573 \\
Sun & 720 & 1031.00 & 13250.00 & 1993.4897 & 646.46890 \\
Rain & 720 & 1067.90 & 4105.40 & 1966.2558 & 423.65871 \\
Humid & 720 & 70.50 & 88.80 & 77.2521 & 4.72209 \\
Temp & 720 & 18.40 & 28.90 & 26.8092 & 2.06466 \\
PGRDP & 720 & .06 & 301.40 & 110.7892 & 48.48590 \\
Human & 720 & 10.20 & 58.25 & 32.9579 & 10.37369 \\
Firm_type & 720 & 0.00 & 1.00 & .1903 & .39279 \\
\hline Valid N & 720 & & & & \\
(listwise) & & & & & \\
(Sourc: Author & & & & &
\end{tabular}

(Source: Author, 2021)

For the variables of sunshine hours (Sun) and rainfall (Rain), we can see that these two variables carry a large standard deviation, indicating the amount of rain and sunshine hours in the areas where the company's headquarters is quite a big difference. Since the sampling group stretches from North to South, this is easy to explain. With the control variables on economic factors, the debt-toassets ratio (Debtas) has a mean of $46 \%$ and a standard deviation of $21 \%$. Besides, the size of the 
company (size) has a standard deviation of $198 \%$, which shows that the size of the company in the manufacturing industry in Vietnam also has a huge difference.

With the macroeconomic variables, PGRDP ratio has an average of 110.79 million dongs, the highest is 301.4 million dongs, the lowest is 0.06 million dongs, the standard deviation is quite high 48.48 million dongs, showing the difference, through which the impact will be seen to the financial performance of the company.

\subsection{Correlation results}

Table 5 provides the Pearson correlations between climate risk and our measures of financial performance. We find that ROS is positively correlated with ROE and ROA. Both climate risk measures are negatively and significantly related to ROA, ROE, and ROS. These univariate correlations are consistent with our hypotheses. The correlation coefficient of the explanatory variables in the research model is low (less than 0.5), multicollinearity is unlikely when performing the estimated regression (Gujarati, 2008). At the same time, according to Kenned (2008), the correlation coefficient between the two variables has a value of absolute value greater than 0.8 , the model is considered to have high multicollinearity defects; copper. Over time, the estimated coefficients easily lose statistical significance and their signs may be opposite to the period hope. The estimated results are unreliable.

Table 5. Correlation matrix

\begin{tabular}{|c|c|c|c|c|c|c|c|c|c|c|c|c|c|c|}
\hline & ROA & ROE & ROS & Debtas & Totalin & Lnsize & Holder & Sun & Rain & Humid & Temp & PGRDP & Human & Firm_type \\
\hline $\begin{array}{l}\text { ROA } \\
\end{array}$ & & & & & & & & & & & & & & \\
\hline ROE & $.529^{* *}$ & 1 & & & & & & & & & & & & \\
\hline ROS & $.629^{* *}$ & $.272^{* *}$ & 1 & & & & & & & & & & & \\
\hline Debtas & $-.393^{* *}$ & -.014 & $.374^{* *}$ & 1 & & & & & & & & & & \\
\hline Totalin & $.142^{* *}$ & $.124^{* *}$ & $.095^{*}$ & $.081^{*}$ & 1 & & & & & & & & & \\
\hline Lnsize & .003 & . 029 & -.017 & .042 & -.022 & 1 & & & & & & & & \\
\hline Holder & $.129^{* *}$ & . 071 & $.118^{* *}$ & $-.078^{*}$ & $-.126^{* *}$ & . 053 & 1 & & & & & & & \\
\hline Sun & $.078^{*}$ & .036 & .047 & $-.093^{*}$ & $-.122^{* *}$ & .039 & $.099^{* * *}$ & 1 & & & & & & \\
\hline Rain & -.007 & -.009 & -.056 & .027 & -.051 & . 031 & . 064 & $.124^{* *}$ & 1 & & & & & \\
\hline Humid & $-.141^{* *}$ & -.066 & $.117^{-*}$ & $.170^{* * *}$ & .041 & . 021 & .039 & -.051 & $.275^{* *}$ & 1 & & & & \\
\hline Temp & $.088^{*}$ & . 043 & .069 & $-.105^{* *}$ & $-.119^{* *}$ & .018 & . 046 & $.432^{* *}$ & $.139^{* *}$ & $-.514^{* *}$ & 1 & & & \\
\hline PGRDP & .057 & .003 & .060 & $-.122^{* *}$ & $-.085^{*}$ & .030 & -.024 & $.231^{* *}$ & $173^{* *}$ & $-.454^{* *}$ & $.517^{* *}$ & 1 & & \\
\hline Human & . 026 & -.032 & .024 & $-.101^{* *}$ & -.002 & -.059 & $-.204^{* *}$ & $263^{* *}$ & $272^{-* *}$ & $-.601^{* *}$ & $.135^{* *}$ & $.166^{* *}$ & 1 & \\
\hline $\begin{array}{l}\text { Firm- } \\
\text { type }\end{array}$ & .034 & $.085^{*}$ & .006 & .016 & $.090^{*}$ & $.192^{* *}$ & -.023 & $.090^{\circ}$ & -.030 & .059 & .000 & $.082^{*}$ & -.017 & 1 \\
\hline
\end{tabular}

*. Correlation is significant at the 0.01 level (2-tailed).

*. Correlation is significant at the 0.05 level (2-tailed).

(Source: Author, 2021)

The correlation coefficients between variables used in the regression models are presented in Table 5. Other correlation coefficients are quite small (below 0.5), implying that other variables are suitable in the regression models. According to the research results, capital structure (debtas) and humidity index (humid), were found to be negatively related to ROA and ROS because all coefficients of pairwise correlation among these variables are negative and significant at the 5\% level. Specifically, the correlation coefficients presenting the link of debtas with ROA and ROS are -0.393 and -0.374 , while the figures of humid are -0.141 and -0.117 , respectively.

\subsection{Regression results}

Table 6 reports the regression results of climate change risks on the financial performance. The impact of risks of sunshine hours (Sun), rain (Rain), and temperature (Temp) on the financial performance of companies are not significant because only a few companies in the manufacturing industry are sensitive to those indicators. Humidity risk (Humid) has a significant and negative correlation with the financial performance of companies. High humidity in the air creates conditions for bacteria and microorganisms to grow, affecting workers' health or directly affecting products. 
Table 6. The effect of climate change risks on firm performance-Pooled OLS regression

\begin{tabular}{|c|c|c|c|}
\hline Variable & ROA & ROE & ROS \\
\hline \multirow{2}{*}{ Sun } & 0.00000742 & 0.00000737 & 0.00000385 \\
\hline & -0.93 & -0.33 & -0.24 \\
\hline \multirow{2}{*}{ Rain } & 0.00000216 & -0.00000371 & -0.0000164 \\
\hline & -0.32 & $(-0.20)$ & $(-1.20)$ \\
\hline \multirow{2}{*}{ Humid } & $-0.00205 * *$ & $-0.00557 * *$ & -0.00206 \\
\hline & $(-2.38)$ & $(-2.31)$ & $(-1.18)$ \\
\hline \multirow{2}{*}{ Temp } & -0.000794 & -0.00114 & -0.00114 \\
\hline & $(-0.39)$ & $(-0.20)$ & -0.25 \\
\hline \multirow{2}{*}{ Debtas } & $-0.146^{* * *}$ & -0.00499 & $-0.281 * * *$ \\
\hline & $(-11.26)$ & $(-0.14)$ & $(-10.68)$ \\
\hline \multirow{2}{*}{ Growth } & $0.0453 * * *$ & $0.0793 * * *$ & $0.0635 * * *$ \\
\hline & -5.72 & -3.58 & -3.96 \\
\hline \multirow{2}{*}{ Size } & $0.00355 * *$ & $0.00641^{*}$ & $0.00596^{* *}$ \\
\hline & -2.57 & -1.66 & -2.13 \\
\hline \multirow{2}{*}{ Holder } & $0.0339 * * *$ & 0.0469 & $0.0453^{*}$ \\
\hline & -2.65 & -1.32 & -1.75 \\
\hline \multirow{2}{*}{ Firm_type } & -0.00514 & -0.00414 & 0.0166 \\
\hline & $(-0.73)$ & $(-0.21)$ & -1.17 \\
\hline \multirow{2}{*}{ PGRDP } & -0.0000631 & -0.000208 & -0.0000923 \\
\hline & $(-0.96)$ & $(-1.14)$ & $(-0.70)$ \\
\hline \multirow{2}{*}{ Human } & -0.017 & -0.128 & -0.0574 \\
\hline & $(-0.46)$ & $(-1.23)$ & $(-0.76)$ \\
\hline \multirow{2}{*}{ Constant } & $0.200^{*}$ & 0.459 & 0.138 \\
\hline & -1.89 & -1.55 & -0.85 \\
\hline Observations & 720 & 720 & 720 \\
\hline Adj R-squared & 0.21 & 0.035 & 0.179 \\
\hline
\end{tabular}

Standard error in parentheses: * significant at the $10 \%$ level; ** significant at the $5 \%$ level; *** significant at the $1 \%$ level.

(Source: Author, 2021)

Capital structure (Debtas) is negatively related to the financial performance of firms in manufacturing. The capital structure was represented by the ratios of short- and long-term liabilities, total liabilities to total assets, and profitability measured by the ROE. The generalized least square technique was applied, and the results suggest that the capital structure of Vietnamese listed non-financial companies is negatively related to their performance (Nguyen and Nguyen, 2020).

Contrary to the above results, the company's growth rate (Growth) and business size (Size) are negatively correlated and have a significant impact on the financial performance of the company. The faster company growth, the larger the market share, the greater the company's competitiveness, and the higher the financial performance of the company which is in agreement with the previous study by (Sun et al., 2020).

Controlling shareholder ownership ratio (Holder) and ownership structure (Firm_type) do not have a significant impact on the financial performance of companies in the manufacturing industry. It may depend on the fact that Vietnamese companies in the manufacturing sector are largely state-owned, and there are slight differences between corporate governance and ownership structures.

Besides, the impact of macroeconomic variables (PGRDP, Human) on the financial performance of companies in the industry is not significant. This may be due to the relatively concentrated between the distribution of companies in a few cities and economic differences. The manufacturing industry has low requirements for labor education, so improving the quality of human resources does not have a clear effect on the performance of the company (Sun et al., 2020).

A critical point is that most of the adjusted $\mathrm{R}$-squared values are moderate. Particularly in ROA and ROS regression, the value of adjusted R-squared is about 0.21 ; reflects that the models can explain $21 \%$ of the variation in ROA and that ROS is much higher than ROE, implying that the effect of ROA and ROE is much stronger than that of ROE. the coefficient of book leverage in the ROA equation is negative and significant at the $1 \%$ level, respectively. These figures in ROE and Tobin $\mathrm{Q}$ equations are insignificant under the proxy of long-term debts to book value of total assets (Vy and Nguyet, 2017). This result is completely consistent with our study. 
Table 7. The effect of climate change ricks on firm performance-HOSE and HNX regression

\begin{tabular}{|c|c|c|c|c|c|c|}
\hline \multirow{2}{*}{ Variable } & \multicolumn{2}{|c|}{ ROA } & \multicolumn{2}{|c|}{ ROE } & \multicolumn{2}{|c|}{ ROS } \\
\hline & HOSE & HNX & HOSE & HNX & HOSE & HNX \\
\hline Sun & $\begin{array}{l}0.0000263 * * \\
(2.19)\end{array}$ & $\begin{array}{l}-0.0000119 \\
(-1.02)\end{array}$ & $\begin{array}{l}0.0000481 \\
(1.30)\end{array}$ & $\begin{array}{l}-0.0000386^{*} \\
(-1.79)\end{array}$ & $\begin{array}{l}0.0000150 \\
(0.55)\end{array}$ & $\begin{array}{l}-0.0000217 \\
(-1.64)\end{array}$ \\
\hline Rain & $\begin{array}{l}0.00000674 \\
(0.73)\end{array}$ & $\begin{array}{l}-0.00000590 \\
(-0.57)\end{array}$ & $\begin{array}{l}-0.000000114 \\
(-0.00)\end{array}$ & $\begin{array}{l}-0.0000168 \\
(-0.89) \\
\end{array}$ & $\begin{array}{l}-0.0000113 \\
(-0.97) \\
\end{array}$ & $\begin{array}{l}-0.0000117 \\
(-0.96)\end{array}$ \\
\hline Humid & $\begin{array}{l}-0.00209 * \\
(-1.75)\end{array}$ & $\begin{array}{l}-0.000786 \\
(-0.57)\end{array}$ & $\begin{array}{l}-0.00579 \\
(-1.57)\end{array}$ & $\begin{array}{l}-0.00290 \\
(-1.14)\end{array}$ & $\begin{array}{l}0.00113 \\
(-0.97)\end{array}$ & $\begin{array}{l}0.000445 \\
(0.72)\end{array}$ \\
\hline Temp & $\begin{array}{l}-0.00267 \\
(-0.85) \\
\end{array}$ & $\begin{array}{l}0.00349 \\
(1.25) \\
\end{array}$ & $\begin{array}{l}-0.00524 \\
(-0.54) \\
\end{array}$ & $\begin{array}{l}0.00704 \\
(1.37) \\
\end{array}$ & $\begin{array}{l}0.00431 \\
(0.61) \\
\end{array}$ & $\begin{array}{l}0.00121 \\
(0.38) \\
\end{array}$ \\
\hline Debtas & $\begin{array}{l}-0.144 * * * \\
(-8.46) \\
\end{array}$ & $\begin{array}{l}-0.161 * * * \\
(-7.34) \\
\end{array}$ & $\begin{array}{l}0.0319 \\
(0.61) \\
\end{array}$ & $\begin{array}{l}-0.0947 * * \\
(-2.34) \\
\end{array}$ & $\begin{array}{l}-0.353 * * * \\
(-9.23) \\
\end{array}$ & $\begin{array}{l}-0.165 * * * \\
(-6.62) \\
\end{array}$ \\
\hline Growth & $\begin{array}{l}0.0459 * * * \\
(4.88) \\
\end{array}$ & $\begin{array}{l}0.0436 * * * \\
(2.80) \\
\end{array}$ & $\begin{array}{l}0.0839 * * * \\
(2.89)\end{array}$ & $\begin{array}{l}0.0790 * * * \\
(2.76)\end{array}$ & $\begin{array}{l}0.0643^{* * * *} \\
(3.04)\end{array}$ & $\begin{array}{l}0.0464 * * \\
(2.63)\end{array}$ \\
\hline Size & $\begin{array}{l}0.00442 * * * \\
(2.83)\end{array}$ & $\begin{array}{l}0.00486 \\
(1.07)\end{array}$ & $\begin{array}{l}0.00729 \\
(1.52)\end{array}$ & $\begin{array}{l}0.0131 \\
(1.55)\end{array}$ & $\begin{array}{l}0.00489 \\
(1.39)\end{array}$ & $\begin{array}{l}0.00471 \\
(0.91)\end{array}$ \\
\hline Holder & $\begin{array}{l}0.00206 \\
(0.13) \\
\end{array}$ & $\begin{array}{l}0.0859 * * * \\
(3.93)\end{array}$ & $\begin{array}{l}-0.00985 \\
(-0.20) \\
\end{array}$ & $\begin{array}{l}0.154 * * * \\
(3.83)\end{array}$ & $\begin{array}{l}0.0375 \\
(1.04)\end{array}$ & $\begin{array}{l}0.0380 \\
(1.53)\end{array}$ \\
\hline Firm_type & $\begin{array}{l}0.0118 \\
(1.41)\end{array}$ & $\begin{array}{l}-0.0502 * * * \\
(-2.79) \\
\end{array}$ & $\begin{array}{l}0.0212 \\
(0.83)\end{array}$ & $\begin{array}{l}-0.0701 * * \\
(-2.11)\end{array}$ & $\begin{array}{l}0.0249 \\
(1.33) \\
\end{array}$ & $\begin{array}{l}-0.0143 \\
(-0.70)\end{array}$ \\
\hline PGRDP & $\begin{array}{l}-0.000178^{*} \\
(-1.95) \\
\end{array}$ & $\begin{array}{l}0.000000517 \\
(0.00)\end{array}$ & $\begin{array}{l}-0.000291 \\
(-1.03) \\
\end{array}$ & $\begin{array}{l}-0.000254 \\
(-1.23) \\
\end{array}$ & $\begin{array}{l}-0.000298 \\
(-1.44) \\
\end{array}$ & $\begin{array}{l}0.0000930 \\
(0.73)\end{array}$ \\
\hline Human & $\begin{array}{l}0.000155 \\
(0.27)\end{array}$ & $\begin{array}{l}-0.000326 \\
(-0.58)\end{array}$ & $\begin{array}{l}-0.000830 \\
(-0.48)\end{array}$ & $\begin{array}{l}-0.00134 \\
(-1.29)\end{array}$ & $\begin{array}{l}-0.00123 \\
(-0.96)\end{array}$ & $\begin{array}{l}0.000621 \\
(0.98)\end{array}$ \\
\hline Constant & $\begin{array}{l}0.191 \\
(1.25)\end{array}$ & $\begin{array}{l}0.00335 \\
(0.02)\end{array}$ & $\begin{array}{l}0.463 \\
(0.98) \\
\end{array}$ & $\begin{array}{l}-0.00405 \\
(-0.01)\end{array}$ & $\begin{array}{l}0.231 \\
(0.67)\end{array}$ & $\begin{array}{l}-0.103 \\
(-0.47) \\
\end{array}$ \\
\hline Observations & 485 & 235 & 485 & 235 & 485 & 235 \\
\hline Adj R-squared & 0.211 & 0.312 & 0.036 & 0.177 & 0.202 & 0.235 \\
\hline
\end{tabular}

Standard error in parentheses: * significant at the $10 \%$ level; ** significant at the $5 \%$ level; *** significant at the $1 \%$ level. (Source: Author, 2021)

In table 7 , we divide and analyze the impact at two stock exchanges, HOSE and HNX. anarters of manufacturing industrial companies translated with T-Statistic values. It always positive in Vietnam are concentrated mainly in the Southeast with $99 \%$ confidence level.

region, where Rainfall is less concentrated and the

The size of the company (Size) has a temperature is more stable than other areas (NCHMF, negligible impact on financial performance. This is true 2021). Meanwhile, the index of sunshine hours (Sun) for companies that expand by increasing charter capital, and air humidity (Humid) have the same and opposite profitability may increase due to large scale, but it is effects on the ROA index on HOSE, showing that still not enough to make the return on total assets companies on HOSE are easily affected. affected by increase significantly. (Amarjit et al., 2010; Falope and these two indicators. The main reason that financial Ajilore, 2009; Ngoc, 2011).

activities are affected by air humidity (humidity) and The shareholding ratio of controlling sunshine hour (sun), companies are mainly shareholders (Holder) and ownership structure concentrated in the Southeast region and the Red River (Firm_type) generall do not significantly affect the Delta with a subtropical climate. Tropic. The sub- financial performance of companies listed on the two equatorial and tropical monsoons are hot and humid all stock exchanges. This is completely consistent with the year round, so they are easily affected by the humidity study of Sheikh and Alom (2021) when board of the air. At the HNX, it showed only a limited impact, composition has no significant impact on company most of the climate change indicators did not affect the performance in the context of Bangladeshi shipping financial performance of companies.

Capital structure (Debtas) is generally Besides, the impact of macroeconomic negatively correlated with financial performance of variables (PGRDP, Human) on the financial companies listed on both HOSE and HNX. Only the performance of companies in the industry in both stock ROE index at the HOSE stock exchange has no exchanges is insignificant. This is consistent with the significant impact. This is completely consistent with previous results. previous results when the impact of ROE is not clear. 
In addition, most of the adjusted R-squared There is no conclusive evidence that temperature and values were moderate, ranging from 0.177 to 0.312 . precipitation have a detrimental influence on financial Except at HOSE exchange, ROE is quite small, performance in the manufacturing business, but it is basically consistent with previous analysis results.

Table 8. Summary of findings

\begin{tabular}{l|r|r|r}
\multicolumn{1}{c}{$\begin{array}{c}\text { Primary } \\
\text { Variable }\end{array}$} & \multicolumn{2}{c}{ ROA } \\
\hline Sun & 0 & 0 & 0 \\
\hline Rain & 0 & 0 & 0 \\
\hline Humid & - & - & 0 \\
\hline Temp & 0 & 0 & 0 \\
\hline Debtas & - & 0 & - \\
\hline Growth & + & + & + \\
\hline Size & + & 0 & + \\
\hline Holder & + & 0 & + \\
\hline Firm_Type & 0 & 0 & 0 \\
\hline PGRDP & 0 & 0 & 0 \\
\hline Human & 0 & - & 0 \\
\hline Source:Author & & &
\end{tabular}

(Source: Author, 2021)

This table summarizes the effects of the independent and control variables on the dependent variable related to the financial performance indicators of companies, and 0 indicates that no significant relation was found.

The air humidity (Humid) index is consistent with the results of our study. While the remaining three indicators of the risks of climate change have different results than the one we compiled in Table The reason may be that the climate in Vietnam includes: the number of hours of sunshine (Sun), rainfall (Rain), and temperature (Temp) do not have a significant impact on companies in the manufacturing industry, especially in some areas such as the Southeast, the Red River Delta where the headquarters of the companies are concentrated.

\section{CONCLUSION}

In this study, we were interested in understanding the comparative effect of climate change risks and manufacturing companies in Vietnam. Using panel data for 144 companies over 5 years from 2015 to 2019, we built an effect model after incorporating several control variables. Our results indicate that climate change risks affect a company's financial performance through negative channels. This paper verified the relationship between climate change risks and financial performance by established a panel data model based on Vietnam's listed manufacturing companies.

According to the impact of climate change, especially, humidity has a strong impact on financial performance and negative correlation with the financial performance of companies because high humidity in the air creates favorable conditions for bacteria and microorganisms to grow directly and indirectly to the products. A prior research concluded that humidity had a detrimental influence on financial performance, which is in line with the results of the correlation. possible that they do since the number of variables investigated is too small and the procedure of variable selection is not consistent because of the short sample size and the restricted number of variables for firms, the results are being followed. For micro variables, the capital structure is negatively correlated with the financial performance of firms in the manufacturing industry because underestimation of bankruptcy costs can leave firms more indebted than they should be necessary needs. Therefore, a high debt ratio will reduce the operating efficiency of the business. The growth of the company and the size of the company both have a positive impact on financial performance and they are suitable with the previous research.

Besides we divide and analyze the impact at two stock exchanges which are HOSE and HNX. The index of sunlight hours and air humidity impact ROE in HNX. The major reason why air humidity and sunshine hours impact financial operations is that firms are situated mostly in the Southeast area and the Red River Delta, which have subtropical climates. Because the sub-equatorial and tropical monsoons are hot and humid all year, they are easily impacted by air humidity. The HOSE alone has a limited influence; most climate change indicators have no discernible impact on corporate financial performance.

Although this research paper has provided certain meaningful results, our team would like to point out some limitations in the article so that it can get better result in the future research papers.

First, according to the data collection process, it is still rudimentary, in the form of manual extraction, without using automated software, which may affect to the accuracy. Data on climate change in Vietnam is still limited and has not been fully updated at the data portals, so the control variables are still incomplete in their aspects to affect the firms' financial performance.

Secondly, in this study, we only focused on the manufacturing industry, testing on 720 samples, which are corresponding to 144 companies in the industry. In the coming time, the authors would expand the number of samples or develop to other industries or for all Vietnamese firms in general.

Finally, the study only using the econometric regression model. In the future, we hope to be able to try with other models for more specific assessments.

\section{REFERENCES}

[1] Baghersad, M. and Christopher, W.Z. (2015), "Economic impact of production bottlenecks caused by disasters impacting interdependent industry sectors", International Journal of Production Economic.

[2] Bhat, A.H., Sharma, K.C., Banday, U.J.(2015), "Impact of Climatic Variability on Salt Production in Sambhar Lake, a Ramsar Wetland of Rajasthan, India", Middle East Journal of Scientific Research, 23(9), 2060-2065 
[3] Bourdeau, M. and Kryzanowski, B.L. (2016), "The impact of natural disasters on the stock returns and volatilities of local firms", Quarterly Review of Economics and Finance, 259-270.

[4] Brei,M., Mohanb, P. and Strobl, E. (2019), "The impact of natural disasters on the banking sector: Evidence from hurricane strikes in the Caribbean", The Quarterly Review of Economics and Finance 72, 232-239.

[5] Chinh, N.T. (2020), "Effects of climate change on our country: Current situation, new problems and solutions".

[6] Dung, T.M., Phong, T.D.N., Quan, H.A., Anh, B.T.D., Nhung, N.T. and Huy, T.Q. (2020), "The factors affecting financial performance of plastic enterprises listed on Vietnam stock market", Journal of Accounting \& Auditing 5/2020.

[7] Ginglinger, E. and Moreau, Q. (2021), "Climate Risk and Capital Structure", Finance Working Paper 737, 4-7.

[8] Hancock, Peter, A., Jennifer, M. R., and James, L. S. (2007). "A Meta-analysis of Performance Response under Thermal Stressors," Human Factors: The Journal of the Human Factors and Ergonomics Society, 49 (5), 851-877.

[9] Hayakawaa, K., Matsuurab, T. and Okubo, F. (2015), "Firm-level impacts of natural disasters on production networks: Evidence from a flood in Thailand", Journal of the Japanese and International Economies, 244-259.

[10] Hieu, N.T and Anh, N.H. (2020), "Capital structure and firm performance of non-financial listed companies: Cross-sector empirical evidences from Vietnam", Contents lists available at Growing Science Accounting, 137-150.

[11] Huang, H. H., Kerstein, J. and Wang, C. (2018). "The impact of climate risk on firm performance and financing choices: An international study", Journal of International Business Studies, 49(5), 633-656.

[12] Javadia, S. and AlMasum, A. (2021), "The impact of climate change on the cost of bank loans", Journal of Corporate Finance, 2-7.

[13] Kliger, D., Raviv, Y., Rosett, J., Bayer, T., \& Page, J. (2015). "Seasonal affective disorder and seasoned art auction prices: New evidence from old masters", Journal of Behavioral and Experimental Economics, 59, 74-84.

[14] Langford, P. (2019), "Dealing with humidity in factories: ventilate or heat?".

[15] Leitold, R., Garschagen, M., Tran,V. and Diez, J.R. (2021), "Flood risk reduction and climate change adaptation of manufacturing firms: Global knowledge gaps and lessons from Ho Chi Minh City", International Journal of Disaster Risk Reduction, 2-4.

[16] Lilja, David, J. (2000). Measuring computer performance: a practitioner's guide, Cambridge University Press.

[17] Merloni, E., Camanzi, L., Mulazzani, L. and Malorgio, G. (2018), “Adaptive capacity to climate change in the wine industry: A Bayesian Network approach" Wine Economics and Policy, 165-177.
[18] Mollah, S.I., Begum, S., Mussen, L.M., Mohamad, S.J. and Mohammad, S. (2020), "The Role of Engineering in Mitigating Global Climate Change Effects: Review of the Aspects of Carbon Emissions from Fossil Fuel-Based Power Plants and Manufacturing Industries", Encyclopedia of Renewable and Sustainable Materials, 750-762.

[19] Mortier, Roy, M., Stefan, T. O., and Malcolm, F. F. (1992). Chemistry and Technology of Lubricants, Springer.

[20] Odella, S.D., Bebbingtona, A. and Frey, K.E. (2018). "Mining and climate change: A review and framework for analysis", The Extractive Industries and Society, 3-9.

[21] Pizarro, J., Sainsbury, B., Hodgkinson, J. and Loechel, P. (2017), "Australian uranium industry climate change vulnerability assessment", Environmental Development, 109-123.

[22] Salim, M. and Yadav, D.R. (2012), "Capital Structure and Firm Performance: Evidence from Malaysian Listed Companies", International Congress on Interdisciplinary Business and Social Science 2012, 2-3.

[23] Schultz, H.R. (2010), "Climate change and viticulture: research needs for facing the future", $J$. Wine Res, 21 (2/3) (2010), 113-116.

[24] Sudarshan, A. and Tewari, M. (2014). "The Economic Impacts of Temperature on Industrial Productivity: Evidence from Indian Manufacturing." ICRIER Paper No. 278.

[25] Sun, Y., Yang, Y., Huang, N. and Zoue, X. (2020), "The impacts of climate change risks on financial performance of mining industry: Evidence from listed companies in China", Resources Policy 69, 13 .

[26] Tuan, D.A., Thach, P.N., Ha, L.T., Chi, B.L. and Trong, T.D (2020), "Đánh giá tác động của biến đổi khí hậu đối với doanh nghiệp Việt Nam”, The Asian Foundation.

[27] Thuy, C.T.T., Huyen, N.T. and Quyen. N.T. (2015), "Phân tích các nhân tố ảnh hưởng hiệu quả tài chính: nghiên cứu điển tại các công ty cổ phần phi tài chính niêm yết trên sở giao dịch chứng khoán thành phố Hồ Chí Minh”, Kinh tế và phát triển, 3-6.

[28] Tan, N.M., Danh, V.T. and Ngan, T.T. (2015), "Factors affecting business efficiency of small and medium business in bac lieu province."

[29] Ullah, A., Pinglu, C., Ullah, S., Zaman, M. and Hashmi, S.H. (2020), "The nexus between capital structure, firm-specific factors, macroeconomic factors and financial performance in the textile sector of Pakistan", Contents lists available at ScienceDirect, 3-4.

[30] Vy, L.T.P. and Nguyet, P.T.B. (2017), "Capital structure and firm performance: Empirical evidence from a small transition country", Research in International Business and Finance, 710-7.

[31] Zeitun, R. And Tian, G. (2014), "Capital Structure and Corporate Performance: Evidence from Jordan”, Forthcoming in Australasian Accounting Business \& Finance Journal, 10-15. 
[32] Zhang, P., Deschenes, O., Meng, K., Zhang, J. chinese manufacturing plants", Journal of (2017). "Temperature effects on productivity and factor reallocation: Evidence from a half million Environmental Economics and Management 88, 117. 